\title{
Advanced Polymeric Materials for Electronic and Energy Applications
}

\author{
Ahmed Esmail Shalan* \\ Department of Electronic \& Magnetic Materials, Advanced Materials Division, Central Metallurgical Research and Development Institute (CMRDI), \\ Egypt
}

Submission: July 27, 2018; Published: July 31, 2018

*Corresponding author: Ahmed Esmail Shalan, Department of Electronic \& Magnetic Materials, Advanced Materials Division, Central Metallurgical Research and Development Institute (CMRDI), Egypt, Email: a.shalan133@gmail.com

Keywords: Advanced; Polymeric materials; Electronic; Energy; Application

\section{Opinion}

Advanced polymeric materials have showed considerable interest over the past few decades due to their tremendous advantageous coming from the combination of conventional polymeric materials and organic conductors [1-3]. Different features like mechanical, electrical, and optical properties can be founded for advanced polymers due to their confined dimensions at the nanoscale level. Advanced conductive polymers (ACPs) with synthetically tunable hierarchical 3D network structures consider to be one of the nanostructured advanced polymers. It shows great potential for a wide range of applications, such as electronics, bioelectronics and energy storage/conversion devices owing to their structural features [4].

Development of polymers with improved high-temperature properties has been catalyzed as well by the improved understanding of relationships between polymer structure, both molecular and morphological, and the physical and mechanical properties of these materials. Advances in modeling of high-temperature heat transfer in polymers have aided in the understanding of how polymers react to extreme environments $[5,6]$. Finally, advances made in processing of high-performance polymers and their composites continue to trigger improvements in their performance in critical applications. Herein, a broad overview of the field of high temperature properties of polymers and polymer composites is presented. The microstructure and physical/chemical properties of ACPs can be tuned by controlling the synthetic conditions such as species of monomers and crosslinkers, reaction temperature, and solvents.

By incorporating other functional polymers or particles into the ACP matrix, hybrid gels have been synthesized with tailored structures. These hybrid gel materials retain the functionalities from each component, as well as enable synergic effects to improve mechanical and electrical properties of ACPs [7]. With these improved properties, ACPs have been explored to enable novel conceptual devices in diverse applications from smart electronics and ultrasensitive biosensors, to energy storage and conversion devices. Synthetically tunable physical/chemical properties of ACPs can emerge as a unique material platform to develop novel multifunctional materials that have the potential to impact electronics, energy, and environmental technologies [8].

\section{References}

1. Wegner G (1981) Polymers with Metal-Like Conductivity-A Review of their Synthesis, Structure and Properties. Angew Chem Int Ed Engl 20(4): 361-381.

2. Shi Y, Yu G (2016) Designing Hierarchically Nanostructured Conductive Polymer Gels for Electrochemical Energy Storage and Conversion. Chem Mater 28(8): 2466-2477.

3. Sadki S, Schottland P, Brodie N, Sabouraud G (2000) The mechanisms of pyrrole electro polymerization. Chem Soc Rev 29: 283-293.

4. Li C, Bai H, Shi G (2009) Conducting polymer nanomaterials: electrosynthesis and applications. Chem Soc Rev 38: 2397-2409.

5. Shi Y, Peng L, Ding Y, Zhao Y, Yu G (2015) Nanostructured conductive polymers for advanced energy storage. Chem Soc Rev 44: 6684-6696.

6. Martin C R (1995) Template Synthesis of Electronically Conductive Polymer Nanostructures. Acc Chem Res 28(2): 61-68.

7. Oh S-G, Im S S (2002) Electroconductive polymer nanoparticles preparation and characterization of PANI and PEDOT nanoparticles. Curr Appl Phys 2(4): 273-277.

8. Liao Y, Li X-G, Kaner R B (2010) Facile Synthesis of Water Dispersible Conducting Polymer Nanospheres. ACS Nano 4(9): 5193-5202. 
This work is licensed under Creative Commons Attribution 4.0 License

DOI: 10.19080/AJOP.2018.01.555564

\section{Your next submission with Juniper Publishers} will reach you the below assets

- Quality Editorial service

- Swift Peer Review

- Reprints availability

- E-prints Service

- Manuscript Podcast for convenient understanding

- Global attainment for your research

- Manuscript accessibility in different formats ( Pdf, E-pub, Full Text, Audio)

- Unceasing customer service

Track the below URL for one-step submission https://juniperpublishers.com/online-submission.php 